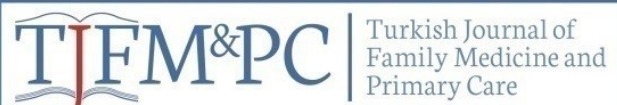

Original Research/Özgün Araştırma

\title{
Investigation of Delay in The Diagnosis of Ankylosing Spondylitis and Associated Factors on The Diagnosis Process
}

\author{
Ankilozan Spondilit Tanı Sürecindeki Gecikme ve Tanı Süreci ile İlişkili \\ Faktörlerin İncelenmesi
}

Erkan Berke ${ }^{1}$, Ümit Aydoğan², Yusuf Ç. Doğaner ${ }^{2 *}$, Sedat Yllmaz ${ }^{3}$

\begin{abstract}
Aim: Since Ankylosing Spondylitis (AS) is an insidious disease, delays may occur in the diagnosis and treatment. This study aims to reveal the initial symptoms, determine the duration between initial symptoms and the time of diagnosis and associated socio-demographic factors. Methods: This cross-sectional study was conducted in the Department of Rheumatology, University of Health Sciences Gulhane Medical Faculty in April 2015 - June 2016. A survey with 25 questions prepared by the researchers was applied to 269 participants by face-to-face interview method. Results: The median duration of the delay time in diagnosis was $2(0.08-16)$ years (mean; $3.28 \pm 3.32)$ years. The current median age was 27 (19-70) years, the median age at onset of symptoms was 21 (4-64) years, and the median age at diagnosis was 24 (11-66) years. Statistically significant positive correlations were found between the delay time in diagnosis and the current age $(r=0.195, p=0.001)$ and the age at diagnosis $(\mathrm{r}=0.247, \mathrm{p}<0.001)$. However, the delay time in diagnosis was inversely correlated with the onset age of symptoms $(\mathrm{r}=-0.186, \mathrm{p}=0.002)$. There was a significant association between the delay time in diagnosis and application to state hospitals $(\mathrm{r}=0.222$, $\mathrm{p}<0.001)$, private hospitals $(\mathrm{r}=0.166, \mathrm{p}=0.008)$. A significant correlation was detected between the delay time in diagnosis and applying to all the specialties except rheumatology. Conclusions: The delay in the diagnosis causes impairment in quality of life and labor loss. It also leads to unnecessary health expenditures and loss of time in diagnosis. The laboratory tests are not sufficient alone. Shortening the diagnostic process is important by carefully evaluating the information obtained from history and physical examination.
\end{abstract}

Keywords: Ankylosing spondylitis, diagnosis, delayed diagnosis.

\section{ÖZET}

Amaç: Ankilozan Spondilit (AS) sinsi seyirli bir hastalık olduğundan, tanı ve tedavide gecikmeler olabilmektedir. Bu çalıșmanın amacı, AS'li hastaların başlangıç semptomları, semptomların başlamasından tanı konulana kadar geçen sürenin saptanması, geç tanı konulmasını ile ilişkili sosyodemogrofik özelliklerin ortaya konmasıdır. Yöntem: Bu kesitsel çalışma Nisan 2015 - Haziran 2016 tarihleri arasında Gülhane Tıp Fakültesi Romatoloji Bilim Dalı’nda gercekleștirilmiștir. Yüz yüze görüsme yöntemiyle uygulanan 25 soruluk anket formu 269

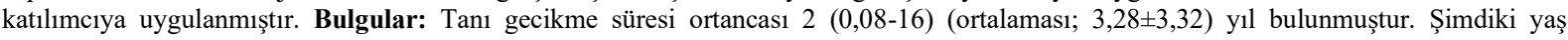

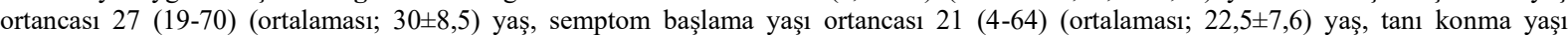

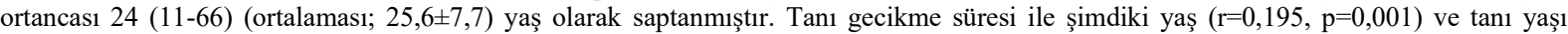
$(\mathrm{r}=0,247, \mathrm{p}<0,001)$ arasında pozitif yönde istatistiksel olarak anlamlı bir korelasyon bulunmuştur. Tanı gecikme süresi ile semptom başlama yaşı $(\mathrm{r}=-0,186, \mathrm{p}=0,002)$ ise ters ilișki bulunmuștur. Calıșmamızda tanı gecikme süresi ile devlet hastanesi $(\mathrm{r}=0,222, \mathrm{p}<0,001)$ ve özel hastaneye $(\mathrm{r}=0,166, \mathrm{p}=0,008)$ başvuru sıklığı arasında anlamlı ilişki tespit edilmiş̧ir. Romatoloji dışında diğer uzmanlık dallarına başvuru ile tanı gecikme süreleri arasında anlamlı korelasyon saptanmıștır. Sonuç: Tanı koymada gecikme nedeni ile özellikle hastaların yaşam kalitesinde azalma ve is gücünde kayıplar ortaya çıkmaktadır. Aynı zamanda bu durum sağlık hizmetlerinde gereksiz harcamalara ve tanı konulma sürecinde zaman kaybına yol açmaktadır. Yapılan tetkikler tek başına yeterli olmamaktadır. Öykü ve fizik muayeneden elde edilen bilgilerin dikkatli şekilde değerlendirilerek tanı sürecini kısaltmak önem arz etmektedir.

AnahtarKelimeler: Ankilozan Spondilit, tanı, gecikmeli tanı

Received Date: 27.06-2019, Accepted Date: 31.07-2019

*1 Family Medicine Center, Hocalar County State Hospital, Afyonkarahisar, Turkey

*22University of Health Sciences, Gulhane Faculty of Medicine, Department of Family Medicine, Ankara, Turkey

*3 University of Health Sciences, Gulhane Faculty of Medicine, Department of Internal Medicine, Division of Rheumatology, Ankara,

Turkey

*Address for Correspondence / Yazıșma Adresi: Yusuf Cetin DOGANER, University of Health Sciences, Gulhane Faculty of Medicine, Department of Family Medicine, Ankara, Turkey

E-mail: yusufcetin.doganer@sbu.edu.tr

Berke E., Aydoğan Ü., Doğaner Y.Ç.,Yılmaz S. Investigation of Delay in The Diagnosis of Ankylosing Spondylitis and Associated Factors on The Diagnosis Process. TJFMPC, 2019;13 (4): 487-499.

DOI: $10.21763 /$ tjfmpc.651510 


\section{INTRODUCTION}

Ankylosing spondylitis (AS) is a chronic, systemic, inflammatory disease with uncertain etiology. It belongs to the group of diseases named as spondyloarthritis which is characterized by the involvement of the axial skeleton (spinal and sacroiliac joints), peripheral joints and enthesis. ${ }^{1,2}$ Since AS is usually insidious, patients often cannot determine the exact time when their complaints begin. ${ }^{3}$ Back and joint pains, the most common symptoms of AS, may not be cared enough by the patient considering it as "common muscle pain" or "unimportant." Most of the patients, even health care professionals may not be able to distinguish between nonspecific and inflammatory back pain. Morning stiffness, which is the most remarkable feature of inflammatory back pain, can last up to 3 hours. Both stiffness and pain tend to decrease with a warm shower and physical activity. Therefore, patients may be delayed in investigating the cause of this complaint, which does not disturb much later in the day. ${ }^{3}$

There is usually no significant change in routine blood tests. ANA (anti-nuclear antibody) and rheumatoid factor (RF) positivity are not different from the healthy population. Increased erythrocyte sedimentation rate (ESR) or C-reactive protein (CRP) levels are within normal limits in most of the patients, although this finding does not exclude the presence of active disease. ${ }^{4,5}$ Therefore, information obtained from history and physical examination is more important in the diagnosis process. Due to the delay in diagnosis, the quality of life of the patients could decrease, and the loss of the labor force may occur. At the same time, this condition leads to unnecessary use of resources in health services and loss of time in the diagnosis process. $^{5}$

This study aimed to determine initial symptoms in patients with AS, the period from onset of symptoms to diagnosis, and predictors associated with the delayed diagnosis.

\section{MATERIAL and METHODS}

\section{Study sample}

The study sample included 269 volunteer patients with AS fulfilling the modified New York classification criteria who were followed in the tertiary inpatient/outpatient clinic of Rheumatology in Gulhane Medical Faculty at 2015 April-2016 June. Inclusion criteria were being older than 18 years of age, willing to participate in the study and giving consent, not to have cognitive dysfunctions, diagnosed with AS or being followed up due to AS. The sample of the study consisted of the employees and their family members together.

\section{Data collection}

After sharing the study information, the data were collected through face-to-face interviews. A 25question survey based on a literature review was used to collect data. Survey form queries sociodemographic characteristics of the patients, first initial symptoms related to AS, health institutions types applied with these symptoms, whether there are other individuals affected in the family, and the duration of the diagnosis process.

\section{Statistical analysis}

Statistical analyses were conducted using the software Statistical Package for the Social Sciences (SPSS for Windows, version 22.0, SPSS Inc., Chicago, IL, USA) program. Mean, standard deviation, median, minimum-maximum variables were used for determining continuous variables and; percentage and numbers were used for determining discrete variables. Normality distribution was analyzed by the KolmogorovSmirnov test. Mann-Whitney U test and KruskalWallis $\mathrm{H}$ test were implemented to compare the groups due to unequal variances. Differences with $p$ $<0.05$ were considered as statistically significant. Spearman correlation analysis was used to detect correlations between variables.

\section{Variables}

Diagnostic process parameters (how long before the first complaints about the disease started, how many applications were made to health centers about these complaints until the diagnosis of AS, specialties of the physicians they applied, health facilities' features.), imaging modalities (sacroiliac joint graphy-SIJG, magnetic resonance imagingMRI), specific laboratory findings (HLA-B27, ESH, CRP) were the dependent variables; whilst socio-demographic features (age, marital status, education, occupation, height, weight, income level, place of residence, exercise status, habits, drugs), any disease other than AS, AS or other 
rheumatologic diseases in family members constitutes the independent variables.

\section{Ethical considerations}

In addition to scientific principles, universal ethical principles were followed in conducting the research. Individuals who participated in the study were informed that they were free to participate in the research, they could drop from the study at any time and the informed consent condition in the research was fulfilled as an ethical principle. Regarding the study protocol, approval was obtained from the Gulhane Medical Faculty NonInterventional Clinical Research Ethics Committee.

\section{RESULTS}

The mean age of 269 (261 male, 8 female) patients was $30 \pm 8.5$ years, and mean body mass index (BMI) was $24.9 \pm 3.9 \mathrm{~kg} / \mathrm{m} 2$. Of the participants, $51.7 \%$ (138) were in normal BMI, 68.3\% (183) were graduates of university, $44.6 \%$ (119) were married, 76.7\% (204) were employed, 58,9\% (155) were in balanced financial income-expenditure situation, $73.2 \%$ (197) were living in provinces, $39.2 \%$ (103) were doing regular exercise, 54.3\% (146) were smoking, $18.9 \%$ (49) were drinking alcohol (Table 1).

Table 1. Distribution of demographic variables of the participants

\begin{tabular}{|c|c|c|}
\hline Variables & & $\%(n)$ \\
\hline \multirow[t]{2}{*}{ Gender } & Male & $97(261)$ \\
\hline & Female & $3(8)$ \\
\hline \multirow[t]{3}{*}{ BMI } & Normal $\left(<24,9 \mathrm{~kg} / \mathrm{m}^{2}\right)$ & $51.7(138)$ \\
\hline & Overweight $\left(25-29,9 \mathrm{~kg} / \mathrm{m}^{2}\right)$ & $39.7(106)$ \\
\hline & Obesity $\left(>30 \mathrm{~kg} / \mathrm{m}^{2}\right)$ & $8.6(23)$ \\
\hline \multirow[t]{3}{*}{ Education level } & Primary school & $14.9(40)$ \\
\hline & High school & $16.8(45)$ \\
\hline & University & $68.3(183)$ \\
\hline \multirow{3}{*}{$\begin{array}{l}\text { Balance of income and } \\
\text { expenses }\end{array}$} & Income $<$ Expenses & $27(71)$ \\
\hline & Income $=$ Expenses & $58.9(155)$ \\
\hline & Income $>$ Expenses & $14.1(37)$ \\
\hline \multirow[t]{2}{*}{ MaritalStatus } & Married & $44.6(119)$ \\
\hline & Single & $55.4(148)$ \\
\hline \multirow[t]{2}{*}{ Employment status } & Employed & $76.7(204)$ \\
\hline & Non-employed & $23.3(62)$ \\
\hline \multirow[t]{2}{*}{ Location } & Province & $73.2(197)$ \\
\hline & Non-province & $26.8(72)$ \\
\hline Regular exercise & Yes & $39.2(103)$ \\
\hline
\end{tabular}




\begin{tabular}{|l|l|c|}
\hline & No & $60.8(160)$ \\
\hline Smoking & Yes & $54.3(146)$ \\
\hline & No & $45.7(123)$ \\
\hline Alcohol & Yes & $18.9(49)$ \\
\hline & No & $81.1(210)$ \\
\hline
\end{tabular}

BMI: Body Mass Index

\section{Table 2. Health institutions where the patients admit and admission frequencies}

\begin{tabular}{|l|c|c|}
\hline \multicolumn{1}{|c|}{ Health facility } & Mean \pm SD & $\begin{array}{c}\text { Median(Min- } \\
\text { Max) }\end{array}$ \\
\hline $\begin{array}{l}\text { Primary care } \\
\text { (family health } \\
\text { center) }\end{array}$ & $1.19 \pm 4.011$ & $0(0-30)$ \\
\hline $\begin{array}{l}\text { Secondary care } \\
\text { (state hospital + } \\
\text { private hospital) }\end{array}$ & $8.14 \pm 13.68$ & $4(0-150)$ \\
\hline University hospital & $4.24 \pm 10.84$ & $1(0-100)$ \\
\hline
\end{tabular}

SD: Standard deviation, Min: Minimum, Max: Maximum

The median value of delay time in diagnosis which was calculated by asking the $\mathrm{s}$ time of diagnosis and the onset time of complaints was 2 (0.08-16) years. The mean age at the diagnosis was $25.6 \pm 7.7$ (11- 66) years; the mean age of symptom onset was $22.5 \pm 7.6(4-64)$ years. The delay time in diagnosis was positively correlated with current age $(r=0.119$, $\mathrm{p}=0.001)$ and the age of diagnosis $(\mathrm{r}=0.247, \mathrm{p}$ $<0.001$ ), whilst symptom onset age was negatively correlated $(\mathrm{r}=-0,186, \mathrm{p}=0.002)$. Distribution of accompanying diseases was as follows; $5(1.9 \%)$ diabetes, $\quad 8(3 \%)$ hypertension, $7(2.6 \%)$ hyperlipidemia, 6 (2.2\%) thyroid disease, 14 (5.2\%) Crohn's disease, 12(4.4\%) LDH, 10 (3.7\%) asthma, and $5(1.8 \%)$ hepatitis.

According to initial complaints of the patients related to AS; ratio of morning stiffness was $85.3 \%$ (227), limitation of waist movements was $77.1 \%$ (205), low back pain lasting longer than 3 months was $59.8 \%$ (159), increased muscle aches was $53.8 \%$ (143) and shoulder pain was 51.9\% (138).

It was determined that the participants most frequently applied to state hospitals and least frequently to private hospitals until the diagnosis of the disease (Table 2). Physical therapyrehabilitation specialists and rheumatology specialists were the most frequently visited physicians during the diagnosis process (Table 3 ).

The most common disease was lumbar disc herniation (LDH) in the rate of $44 \%$ (87) among the first diagnoses of the participants ( $\mathrm{n}=$ 197) during the first application to health institutions (Figure 1). Ratio of family members followed up due to AS history was $30 \%$ (81). 


\begin{tabular}{|l|c|c|}
\hline \multicolumn{2}{|c|}{ Table 3. Application frequency to specialists } \\
\hline \multicolumn{1}{|c|}{ Division } & Mean \pm SD & $\begin{array}{c}\text { Median (Min- } \\
\text { Max) }\end{array}$ \\
\hline Family Medicine & $1,16 \pm 4,35$ & $0(0-40)$ \\
\hline Internal Medicine & $1,76 \pm 4,54$ & $0(0-50)$ \\
\hline $\begin{array}{l}\text { Physical therapy- } \\
\text { rehabilitation }\end{array}$ & $4,48 \pm 7,09$ & $2(0-50)$ \\
\hline $\begin{array}{l}\text { Orthopedics and } \\
\text { traumatology }\end{array}$ & $2,02 \pm 5,08$ & $1(0-70)$ \\
\hline Neuro-surgery & $1,12 \pm 2,67$ & $0(0-20)$ \\
\hline Rheumatology & $3,24 \pm 8,6$ & $0(0-100)$ \\
\hline
\end{tabular}

SD: Standard deviation, Min: Minimum, Max: Maximum

Table 4. The relationship between the demographics of the participants and the delay time in diagnosis

\begin{tabular}{|c|c|c|c|c|}
\hline & & & Diagnostic delay time & \\
\hline \multirow[t]{2}{*}{ Variables } & & $\%(n)$ & Mean \pm SD & $\mathbf{p}^{*}$ \\
\hline & & & Med(min-max) & \\
\hline \multirow[t]{4}{*}{ Gender } & Male & $97(261)$ & $3.246 \pm 3.233$ & \\
\hline & & & $2(0.08-16)$ & 0,952 \\
\hline & Female & $3(8)$ & $4.302 \pm 5.68$ & \\
\hline & & & $1,75(0.08-14.75)$ & \\
\hline \multirow[t]{4}{*}{ Marital status } & Married & $44.6(119)$ & $3.63 \pm 3.26$ & \\
\hline & & & $2,17(0.08-14)$ & 0,026 \\
\hline & Others & $55.4(148)$ & $2.98 \pm 3.37$ & \\
\hline & & & $2(0.08-16)$ & \\
\hline \multirow[t]{3}{*}{ Employmentstatus } & Employed & $76.7(204)$ & $3.44 \pm 3.45$ & \\
\hline & & & $2(0.08-15.08)$ & 0,476 \\
\hline & Nonemployed & $23.3(62)$ & $2.83 \pm 2.84$ & \\
\hline
\end{tabular}




\begin{tabular}{|c|c|c|c|c|}
\hline & & & $2(0.08-16)$ & \\
\hline \multirow[t]{4}{*}{ Location } & Province & $73.2(197)$ & $3.51 \pm 3.46$ & \\
\hline & & & $2.08(0.08-16)$ & 0,041 \\
\hline & Rural & $26.8(72)$ & $2.64 \pm 2.82$ & \\
\hline & & & $1.25(0,08-14)$ & \\
\hline \multirow[t]{4}{*}{ Physical activity } & Yes & $39.2(103)$ & $3.55 \pm 3.61$ & \\
\hline & & & $2(0.08-15.08)$ & 0,57 \\
\hline & No & $60.8(160)$ & $2.98 \pm 2.88$ & \\
\hline & & & $2(0.08-16)$ & \\
\hline \multirow[t]{4}{*}{ Smoking } & Yes & $54.3(146)$ & $3.25 \pm 3.28$ & \\
\hline & & & $2(0.08-15.08)$ & 0,841 \\
\hline & No & $45.7(123)$ & $3,31 \pm 3,37$ & \\
\hline & & & $2(0.08-16)$ & \\
\hline \multirow[t]{6}{*}{ Alcohol drinking } & Yes & $18.9(49)$ & $2.96 \pm 2.57$ & \\
\hline & & & $2.08(0.08-12)$ & 0,845 \\
\hline & No & $81.1(210)$ & $3.40 \pm 3.51$ & \\
\hline & & & $2(0.08-16)$ & \\
\hline & Normal $\left(<24.9 \mathrm{~kg} / \mathrm{m}^{2}\right)$ & $51.7(138)$ & $3.04 \pm 3.28$ & \\
\hline & & & $2(0.08-16)$ & \\
\hline \multirow[t]{6}{*}{ BMI } & Overweight (25-29.9 kg/m²) & $39.7(106)$ & $3.55 \pm 3.44$ & $0,339 * *$ \\
\hline & & & $2(0.08-14.17)$ & \\
\hline & Obesity $\left(>30 \mathrm{~kg} / \mathrm{m}^{2}\right)$ & $8.6(23)$ & $3.02 \pm 1.8$ & \\
\hline & & & $3(0.08-7)$ & \\
\hline & Primary & $14.9(40)$ & $2.83 \pm 3.32$ & \\
\hline & & & $2(0.08-15)$ & \\
\hline \multirow[t]{6}{*}{ Education } & High school & $16.8(45)$ & $3.58 \pm 3.37$ & $0,414^{* *}$ \\
\hline & & & $2.25(0.08-15.08)$ & \\
\hline & University & $68.3(183)$ & $3.29 \pm 3.32$ & \\
\hline & & & $2(0.08-16)$ & \\
\hline & Income $<$ expense & $27(71)$ & $2.85 \pm 3.38$ & \\
\hline & & & $2(0.08-16)$ & \\
\hline $\begin{array}{l}\text { Socioeconomic } \\
\text { status }\end{array}$ & Income $=$ expense & $58.9(155)$ & $3.54 \pm 3.37$ & $0,191 * *$ \\
\hline
\end{tabular}




\begin{tabular}{|l|l|l|c|c|}
\hline & & & $2.25(0.08-15.08)$ & \\
\hline & Income>expense & $14.1(37)$ & $2.82 \pm 2.52$ & \\
\hline & & & $2(0.08-9)$ & \\
\hline
\end{tabular}

SD: Standard deviation, Med: Median, Min: Minimum, Max: Maximum

*Mann-Whitney U test

** Kruskal-Wallis H Test

Table 5. The relationship between the diagnostic delay time and other chronic diseases

\begin{tabular}{|c|c|c|c|c|c|c|c|c|c|c|}
\hline & \multicolumn{2}{|c|}{$\begin{array}{c}\text { Heart } \\
\text { Diseases }\end{array}$} & \multicolumn{2}{|c|}{ DM } & \multicolumn{2}{|c|}{ HT } & \multicolumn{2}{|c|}{ Hypercholesterolemia } & \multicolumn{2}{|c|}{ Thyroid disease } \\
\hline & + & - & + & - & + & - & + & - & + & - \\
\hline $\begin{array}{l}\text { Diagnostic } \\
\text { delay time } \\
\text { Mean } \pm \text { SD } \\
\text { Med(min- } \\
\max )\end{array}$ & $\begin{array}{l}3.64 \quad \pm \\
2,50 \\
4(0.17- \\
7)\end{array}$ & $\begin{array}{l}3.26 \pm \\
3,35 \\
2 \\
(0.08- \\
16)\end{array}$ & $\begin{array}{l}5.82 \quad \pm \\
2,98 \\
6 \quad(3- \\
10.08)\end{array}$ & $\begin{array}{l}3.23 \quad \pm \\
3.31 \\
2(0.08- \\
16)\end{array}$ & $\begin{array}{l}3.71 \quad \pm \\
2.55 \\
2.7(1.67- \\
9.17)\end{array}$ & $\begin{array}{l}3.26 \quad \pm \\
3.34 \\
2(0.08- \\
16)\end{array}$ & $\begin{array}{l}5.71 \pm 5,39 \\
6(0.08-15)\end{array}$ & $\begin{array}{l}3.21 \pm 3.24 \\
2(0.08-16)\end{array}$ & $\begin{array}{l}5.60 \quad \pm \\
5.57 \\
3(1.08- \\
14.75)\end{array}$ & $\begin{array}{l}3.22 \pm \\
3.25 \\
2(0.08- \\
16)\end{array}$ \\
\hline $\mathbf{p}^{*}$ & \multicolumn{2}{|c|}{0.366} & \multicolumn{2}{|c|}{0.039} & \multicolumn{2}{|c|}{0.257} & \multicolumn{2}{|c|}{0.271} & \multicolumn{2}{|c|}{0.192} \\
\hline
\end{tabular}

DM: Diabetes mellitus, HT: Hypertension, SD: Standard deviation, Med: Median, Min: Minimum, Max: Maximum.

Table 6. The relationship between the application to different specialties and the diagnostic delay time

\begin{tabular}{|l|c|c|}
\hline \multicolumn{1}{|c|}{ Specialty } & $\mathbf{r}^{*}$ & $\mathbf{p}$ \\
\hline Family Medicine & 0.122 & 0.048 \\
\hline $\begin{array}{l}\text { Physical therapy and } \\
\text { rehabilitation }\end{array}$ & 0.158 & 0.01 \\
\hline Orthopedics and traumatology & 0.206 & 0.001 \\
\hline Neuro-surgery & 0.204 & 0.001 \\
\hline Rheumatology & -0.055 & 0.381 \\
\hline Internal Medicine & 0.265 & $<0.001$ \\
\hline
\end{tabular}

*Spearman correlation 
When the patients were questioned about the family history regarding the rheumatologic diseases, AS was the leading one $(30 \%)$. The frequencies of the other diseases were as follows: $18.3 \%$ (49) for rheumatoid arthritis (RA), 3\% (8) for inflammatory bowel disease (IBD), $1.5 \%$ (4) for psoriasis, $1.5 \%$ (4) for Familial Mediterranean Fever (FMF), $0.74 \%$ (2) for fibromyalgia and $0.74 \%$ (2) for Sjogren's syndrome.

The most used two drugs in the treatment of AS were Anti-TNF drugs [46.1\% (124) ] and NSAIDs [45.7\% (123) ] (Figure 2). Of the patients, $77.2 \%$ (207) had undergone magnetic resonance imaging (MRI) including the results of active inflammation (44.4\%), chronic changes (17.5\%) and normal (15.3\%). Human leukocyte antigen (HLA) was positive in $30.6 \%$ (82) of the participants (Figure 3)
Evaluation of the relationship between the demographic data and the diagnostic delay time of the participants demonstrated that married patients than single ones $(p=0.026)$, patients living in the province than rural $(p=0.041)$ more likely have greater delay time in diagnosis. No statistically significant difference was found between the diagnostic delay time and the variables of gender, educational status, socio-economic status, working status, exercise, BMI, smoking, alcohol drinking $(\mathrm{p}>0.05)$ (Table 4).

When chronic diseases other than AS were evaluated, no statistically significant difference was found between chronic diseases and diagnostic delay time $(p>0.05)$ except those with and without diabetes $(\mathrm{p}=0.039)$ (Table 5).

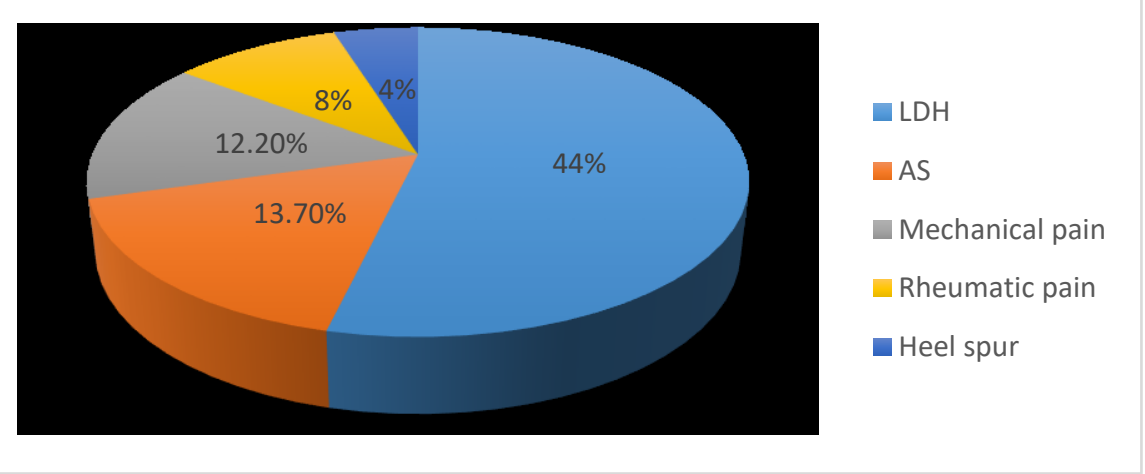

LDH, Lumbar disc herniation; AS, Ankylosing Spondylitis.

Figure 1. Distribution of first diagnoses in health institutions during the application process associated complaints with AS. 


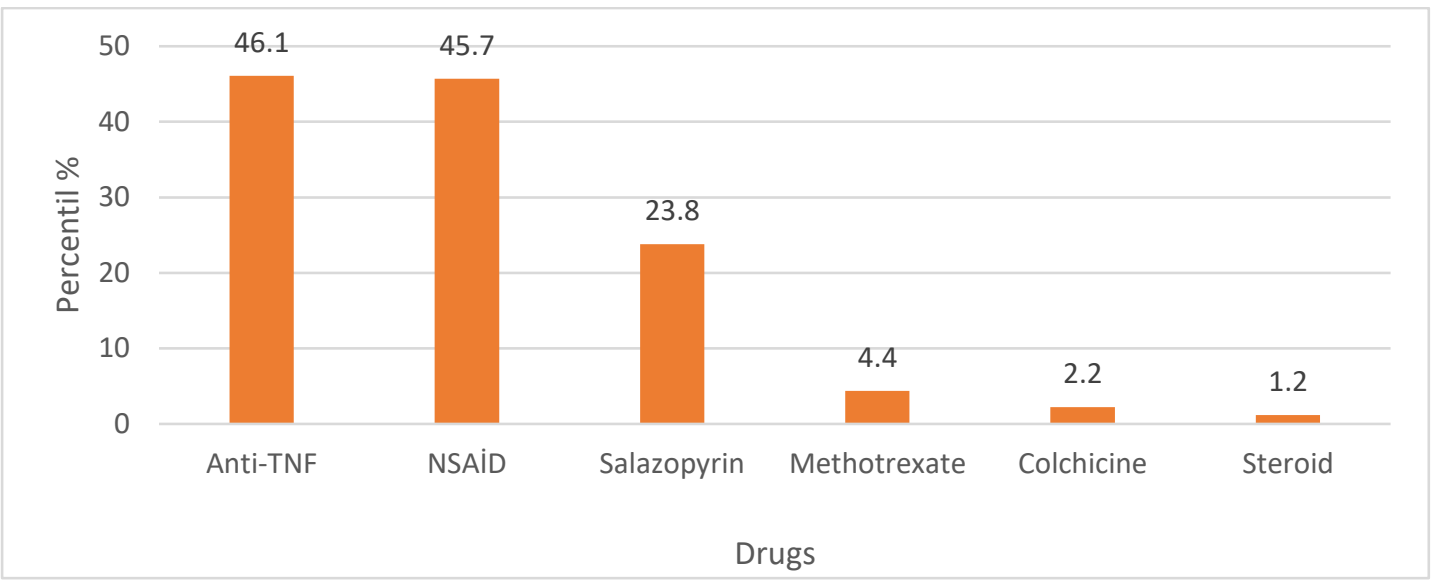

Anti-TNF, Anti-tumor necrosis factor; NSAIDs, Non-steroidal anti-inflammatory drugs; Mtx, Methotrexate.

Figure 2. Drugs used in the treatment of AS (\%)

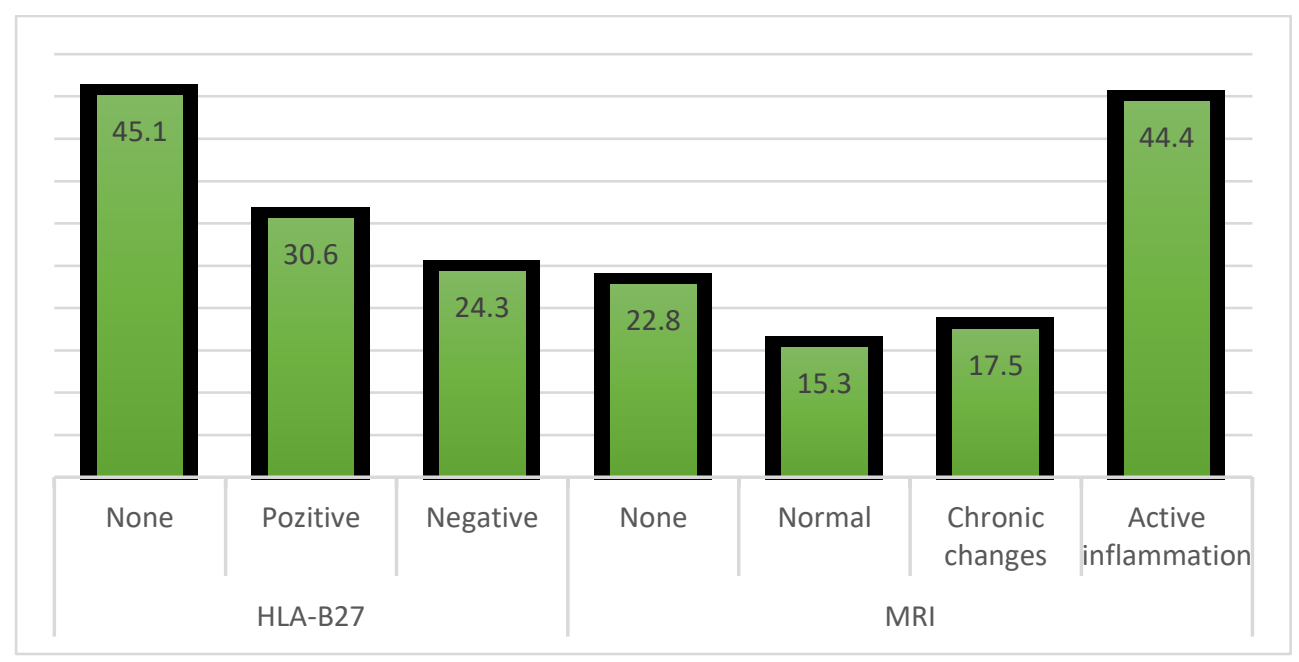

HLA, human leukocyte antigen; MRI, Magnetic resonance imaging.

Figure 3.Distribution of MRI and HLA status of the patients (\%)

A statistically significant positive correlation was detected between the delay time of diagnosis and frequency of admittance to a state hospital $(\mathrm{r}=0.222, \mathrm{p}<0.001)$, and private hospital $(\mathrm{r}=0.166$, $\mathrm{p}=0.008)$ when the type of health care institutions that the patients applied were evaluated. Furthermore, a significant correlation was found out between the diagnostic delay time and all the specialties applied by the patients except rheumatology (Table 6).

\section{DISCUSSION}

In our study, the socio-demographic characteristics, initial symptoms and diagnosis process of AS patients were evaluated. Delay in diagnosis both in Turkey and in the world varies from 4.5 to 8 years. In our study, the median time of diagnosis delay of AS which was determined by asking the time of diagnosis and onset of initial symptoms was 2 years (min:0,08-max:16) (Mean $\pm \mathrm{SD} ; 3.28 \pm 3.32)$. The current median age was $27(19-70)(30 \pm 8.5)$ years, the median age at onset of symptoms was 21 (4-64) $(22.5 \pm 7.6)$ years, the median age at diagnosis was 24 (11-66) $(25.6 \pm 7.7)$ years. A statistically 
significant positive correlation was found between the diagnosis delay time and the current age, the age of diagnosis, but a negative correlation with the symptom onset age. Current age and age at diagnosis was positively correlated with delay time in diagnosis, whilst age at onset of initial symptoms was negatively correlated. In other words, the older patient's current age and age at diagnosis caused longer delay time in diagnosis, but the earlier time at the onset of initial symptoms prolonged the delay time in diagnosis.

It is important to preserve the quality of life of the patient as much as possible during the treatment and follow-up of chronic diseases. One of the main tasks of the physician is to provide early diagnosis of insidious diseases such as AS, as well as to stop the pathological progression of the disease. Strict follow-up of the disease with early diagnosis and treatment may allow for the prevention of problems that could lead to worsening of the quality of life. ${ }^{1,2}$ Since AS is usually insidious, patients often cannot determine the exact time and location of the body part where their complaints begin. ${ }^{3}$ Most of the patients may not be able to distinguish nonspecific back pain from inflammatory causes. Early diagnosis, treatment, and follow-up are important for such a disease which impairs the quality of life with functional and structural limitations. , $^{2,6}$

In the studies from Turkey, the delay time in diagnosis was $8.1 \pm 8.6$ years in the study of Gerdan et al ${ }^{7}$ and $4.6 \pm 6$ years in the study of Aytekin et al. 8 Studies conducted abroad demonstrated that the delay time in diagnosis was $6.2 \pm 3.5$ years in Iran ${ }^{9}, 8$ years in Korea ${ }^{10}$, and 6.7 \pm 5.6 years in Japan. ${ }^{11}$ In our study, the mean delay time in diagnosis was found to be $3.28 \pm 3.32$ years which was calculated by asking the duration between initial symptoms and the time of diagnosis of AS. The average delay time of diagnosis in our study was lower than the studies in our own country, while mean of the delay time of diagnosis in other studies conducted in Turkey were similar to average values in other countries. The current study was conducted in a hospital that provides health service mainly to military personal. The military personals are being asked and examined regularly about their health status. This might explain a relatively short diagnostic delay observed in our patients.
The main reason for the delay in diagnosis is that the results of conventional laboratory and imaging methods are usually normal in patients with AS. It takes several years to develop bone abnormalities in the sacroiliac joints when assessed by conventional radiography. At this point, MRI has taken an increasing role in detecting sacroiliitis. The use of MRI is thought to be effective in the absence of "apparent" sacroiliitis with conventional radiography. Since our study sample is composed of younger patients, MRI was used in most of the patients for either making or confirming the diagnosis.

Low back pain is one of the leading causes of primary care health service admissions. This symptom should be evaluated more carefully in terms of inflammatory diseases, the information obtained from the history, and physical examination should be considered even if no signs are detected in conventional radiographs. The presence of the features of inflammatory back pain should always be queried in detail in young patients with low back pain. Patients with low back pain at onset had a higher delay time. Physicians probably had the strategies for identification of AS more focusing on arthritis than on low back pain. ${ }^{12}$ Based on realworld experience, the most commonly reported misdiagnoses were back problems (44.3\%), psychosomatic disorders $(36.2 \%)$ on the process of the diagnosis of AS. ${ }^{13}$ The leading diagnose (most likely misdiagnose) in our patients was lumbar disc herniation which demonstrates the insufficient evaluation of the patients and unnecessary ordering lumbar spine MRI tests. The first step of a correct diagnosise is to remember the disease, this golden rule is also the case for AS. Expanding the awareness about spondylo-arthritis is essential to decrease the diagnostic delay in these young patients.

The mean diagnosis age in the present study was $25.6 \pm 7.7$ years, whilst $33.9 \pm 10.8$ years in the study of Gerdan et al. ${ }^{7}$ The age of diagnosis in our study was found earlier than the other studies on this subject. Therefore, the diagnostic delay time was shorter in our results than in the other studies. Characteristics of patients who had easy access to health services and regular health checks could be effective in this condition. It is also believed that military personnel is obliged to engage in sportive activities and because of the pain caused by AS, these limited activities could be responsible from 
the earlier hospital admission about the low back pain.

When the patients were asked about the diseases other than AS, there was a significant difference between the delay time in diagnosis in patients with DM compared to the ones who had not DM. We found out limited literature on chronic diseases and late diagnosis of AS. To our knowledge, only Deodhar A. et al reported that the patients with AS who had diabetes mellitus (5.1\%) were less likely referred to rheumatologists than those without diabetes mellitus $(9.8 \%) .{ }^{14}$ One of the reasons for longer diagnostic delay times in diabetic patients than non-diabetic patients may be due to sensory neuropathies that cause the feeling in the later stages of the disease. Another reason for the difference in diabetic patients may be that physicians who follow the patients care more about diabetes-related problems and overlook the symptoms that they think might be simpler.

The relationship between the health institution type and the delay-time in diagnosis demonstrated that there was a mild significant association between the delay time and the frequency of admission to public and private hospitals. It was considered that the patients who apply to these health-care facilities are latediagnosed, and those who cannot get appropriate diagnosis and treatment apply to health institutions with the same competence repeatedly. The quality of life of the patient is adversely affected by the delay in treatment. Functional and structural limitations may occur in patients with progression of the disease.

In the current study, the most preferred specialists consulted for the symptoms were physical therapy and rehabilitation specialists and rheumatologists. In the study of Gerdan et al. ${ }^{7}$, the physical therapy and rehabilitation specialistswere the most popular consultant physicians $(30 \%)$, whilst rheumatologists were the least one $(4 \%)$. This result is normal considering that there are a few rheumatologists in our country and that it is more difficult for patients to reach the rheumatologist than the other specialists. In the study of Gerdan et al. ${ }^{7}$, the minimum average diagnosis delay $(2.9 \pm 5.3$ years $)$ was found by the rheumatology specialist. The branch with the longest diagnostic delay was the orthopedics specialists with $9.6 \pm 9.1$ years and $25 \%(n=99)$ of consulted patients. In our study, a positive moderate correlation was found between the frequency of referral to the internists and the diagnosis delay period.

In our study, there was a positive and moderate relationship between the frequency of referral to internal medicine specialists and the diagnosis delay period. There was a mild significant relationship between the frequency of admission to the other specialists and the diagnostic delay period except for rheumatologists. Since AS is not often treated by the internists and is relatively rare, it may not be among the first diagnoses. Considering the occupational intensities of internists during daily practice, it is more likely to overlook non-specific and rare AS-related symptoms and cannot be considered in preliminary diagnoses.

In our study, $44 \%$ (87) of the participants were diagnosed with $\mathrm{LDH}$ and, $13.7 \%$ (27) was diagnosed as AS at the first admission to health institutions. Gerdan et al. ${ }^{7}$ reported that $33 \%$ of the patients were diagnosed with $\mathrm{LDH}$ and $13.7 \%$ with AS.7 Our results are consistent with literature. Based on these results in the current study, patients were diagnosed with false LDH about three times more than the correct diagnosis. Therefore, patients should be questioned carefully and should not be wasted time with misdiagnosis during the diagnostic process.

\section{Study limitations}

In our study, 269 (261 male, 8 female) patients with AS were interviewed. In other studies, the number of female patients was relatively higher. Although the total number of participants in the current study is highenough, the low number of women was the most important limitation of the study. The patient sample consisted mostly of males because the hospital where we conducted our study was a reference center where whether applicants were suitable for military service is evaluated and wellknown health-care facility preferred by an employee or retired military personnel. Secondly, the mean age of the participants in our study was lower than the other studies. Because the group consisted mostly of participants under military service, the average age was younger than the other studies. Thirdly, we could not measure the quality of life objectively in patients with AS in the current study. Finally, since our study was based on the information obtained from the participants, patients 
with an insidious onset disease such as AS could not remember the dates when their complaints started.

\section{Conclusion}

As a result, the information obtained from medical history and physical examination is important in the diagnosis process of AS. The laboratory and imaging methods are not sufficient alone. Low back pain is the most significant symptoms for family physicians which should be carefully considered among other confounding factors for the differential diagnosis. Due to the delay in diagnosis, the quality of life of the patients decreases and the loss of the labor force occur. Mismanagement of the diagnostic process also leads to unnecessary use of resources in health services. Physicians with high awareness and knowledge level about AS symptoms, the more careful evaluation of the information obtained from the medical history and physical examination will shorten the diagnosis process and prevent unnecessary losses.

\section{Conflicts of interest}

The authors state that they have no conflict of interest.

\section{REFERENCES}

1. Gran JT, Husby G. Epidemiology of ankylosing spondylitis. In: Hochberg MC, Silman AJ, Smolen JS, Weinblatt ME, Weisman $\mathrm{MH}$ (Eds.). Third edition Rheumatology vol. 2. Edinburg: Mosby, Elsevier Limited; 2003, p.11539.

2. Khan MA. Clinical features of ankylosing spondylitis. In: Hochberg MC, Silman AJ, Smolen JS, Winblatt ME, Weisman MH (eds). Rheumatology. Edinburgh: Mosby, 2003: 1161-82.

3. Calin A, Porta J, Fries JF, Schurman DJ. Clinical history as a screening test for ankylosing spondylitis. JAMA 1977; 237: 2613-4.

4. Sheehan NJ, Slavin BM, Donovan MP, Mount JN, Mathews JA. Lack of correlation between clinical disease activity and erythrocyte sedimentation rate, acute phase proteins or protease inhibitors in ankylosing spondylitis. $\mathrm{Br} J$ Rheumatol 1986; 25: 171-4.

5. Spoorenberg A, van der Heijde D, de Klerk E, Dougados M, de Vlam K, Mielants H, et al. Relative value of erythrocyte sedimentation rate and C-reactive protein in assessment of disease activity in ankylosing spondylitis. J Rheumatol 1999; 26: 980-4.

6. Davis JC. Ankylosing spondylitis. In: Koopman WJ, Moreland LW (eds). Arthritis and Allied Conditions. Philadelphia: LWW, 2005:131934.

7. Gerdan V, Akar S, Solmaz D, Pehlivan Y, Onat AM, Kisacik B, et al. Initial diagnosis of lumbar disc herniation is associated with a delay in diagnosis of ankylosing spondylitis. J Rheumatol 2012; 39: 1996-9.

8. Çaðlar NS, Burnaz Ö, Akýn T, Özgönenel L, Çetin E, Aytekin E, et al. Demographic and Clinical Properties and Medical Treatments of Patients Followed as Ankylosing Spondylitis. Ýstanbul Med J 2011; 12: 19-24.

9. Hajialilo M, Ghorbanihaghjo A, Khabbazi A, Kolahi S, Rashtchizadeh N. Ankylosing spondylitis in iran; late diagnosis and its causes. Iran Red Crescent Med J 2014; 16: e11798.

10. Seo MR, Baek HL, Yoon HH, Ryu HJ, Choi HJ, Baek HJ, et al. Delayed diagnosis is linked to worse outcomes and unfavourable treatment responses in patients with axial spondyloarthritis. Clin Rheumatol 2015; 34: $1397-$ 405.

11. Nakashima Y, Ohishi M, Okazaki K, Fukushi J, Oyamada A, Hara D, et al. Delayed diagnosis of ankylosing spondylitis in a Japanese population. Mod Rheumatol 2016; 26: 421-5.

12.Bandinelli F, Salvadorini G, Delle Sedie A, Riente L, Bombardieri S, Matucci-Cerinic $M$. Impact of gender, work, and clinical presentation on diagnostic delay in Italian patients with primary ankylosing spondylitis. Clin Rheumatol. 2016;35:473-8.

13. Ogdie A, Benjamin Nowell W. Real-World Patient Experience on the Path to Diagnosis of Ankylosing Spondylitis. RheumatolTher. 2019; 6:255-67. 
14. Deodhar A, Mittal M, Reilly P, Bao Y, Manthena S, Anderson J, Joshi A. Ankylosing spondylitis diagnosis in US patients with back pain: identifying providers involved and factors associated with rheumatology referral delay. Clin Rheumatol. 2016;35:1769-76. 